\title{
Effects of Sorghum on Broilers Gastrointestinal Tract
}

http://dx.doi.org/10.1590/1516-635x170195-102

\section{-Author(s)}

Silva MCA'

Carolino ACXG

Litz $\mathrm{FH}^{\prime}$

Fagundes NS

Fernandes $\mathrm{E}$ de $\mathrm{A}^{\prime \prime}$

Mendonça GA"I

M. Sc. Students of the Post-Graduation Program in Veterinary Sciences, Universidade Federal de Uberlândia, Brazil

" Prof. Dr., Post-Graduation Program in Veterinary Sciences, Universidade Federa de Uberlândia, Brazil

III Veterinarian.

\section{Mail Address}

Corresponding author e-mail address

Marina C.A. Silva - Rua Ceará, s/n, bloco $2 \mathrm{~d}$ sala 36, Bairro Umuarama.Uberlândia-MG CEP:38400-902 - Telefone: (34) 32182371 (34) 91902541

E-mail: marinacruvinel@hotmail.com

\section{nKeywords}

Alternative feedstuffs, intestine, nutrition, organs.

\section{ABSTRACT}

This study aimed at evaluating the effects of whole and ground sorghum, compared with ground corn, on the live weight, feed conversion ratio, organs weight and intestinal biometrics and histomorphometrics. In total, 960 Hubbard Flex broilers were reared until 42-day-old and distributed into 24 pens, according to the three treatments: ground corn, whole-grain sorghum, and ground sorghum. On day 42 , five male birds per treatment were selected by similar body weight and sacrificed. Gizzard absolute weight, and proventriculus, liver, pancreas and heart relative weights, and duodenum, jejunum, ileum, ceca, and colon length and relative weight were determined. Villus characteristics and intestinal mucosa absorption surface area were evaluated. Broilers fed sorghum, independently of physical form, were heavier and had greater feed conversion ratio than those fed ground corn. Gizzard showed the highest relative weight in broilers fed whole sorghum compared to corn. Liver and jejunum relative weight was higher in broilers fed ground corn, compared to ground sorghum. Whole small intestine, cecum and colon relative lengths showed no difference among treatments. Deeper crypts were found in the duodenum of broilers fed whole grain sorghum, compared to ground sorghum, as well as in jejunum compared to ground corn; however, intestinal absorption surface area was not different among treatments. Whole or ground grain sorghum may replace corn in the feed of 1- to 42-d-old broilers, since they improve body weight and feed conversion ratio, and not adversely affect intestinal morphometry and organs weight.

\section{INTRODUCTION}

The digestive tract of broilers is still not fully developed immediately after hatching, but it quickly matures, considering the short life span of these birds (Uni et al., 1998). Understanding broiler digestive morphology and function is essential to obtain maximum feed efficiency and weight gain.

According to Maiorka et al. (2002), small intestine of birds is the main site of nutrients digestion and absorption. An important component in these segments is the intestinal villi, which increase the contact surface with the food, enabling greater absorption of nutrients. The physicalchemical characteristics of feedstuffs influence the anatomy and the histology of digestive organs, and consequently, the process of nutrient absorption. Therefore, the integrity of the intestinal tissue structure is an indication of the functional and nutritional quality of feedstuffs.

The use of sorghum (Sorghum bicolor (L.) Moench), to replace corn in feeds is economically attractive due to the recent increases in corn prices (Garcia et al., 2013). The culture of sorghum has a high potential 
for grain production per unit area and can be produced in hot dry environment (Carolino et al., 2014). Garcia et al. (2005) evaluated the performance and meat quality of broilers, and found no negative effect of corn replacing for sorghum, as well as Morais et al. (2002), Pimentel et al. (2007) and Rocha et al. (2008), who observed that the use of sorghum as an alternative to corn proved advantageous in broilers diets.

In poultry, cereal grains are generally ground prior to incorporation into feed. However, the use whole grain has increased in order to reduce feed costs caused by transport and processing. This mode of feeding has also been shown to improve performance, wich may be due to modifications of the digestive tract of poultry (Gabriel et al., 2008).

Therefore, the objective of the present study was to evaluate the effect of the dietary inclusion of tannin-free whole or ground sorghum, as compared to corn, on the live weight, feed conservion ratio, organs weight and intestinal biometrics and histomorphometrics of 42-day-old broilers.

\section{MATERIALS AND METHODS}

Broilers were reared at Glória experimental farm of the Federal University of Uberlândia (UFU), located in Uberlândia, state of Minas Gerais, Brazil. The study was carried out during the second half of 2011, and was approved by the Committee of Ethics on Animal Use of that university under protocol number 077/11.

In total, 960 one-day-old Hubbard Flex broilers were distributed in 24 pens, according to the three treatments. Each pen housed 40 sexed broilers, with 20 males and 20 females, totaling eight pens replicates per treatment.

A four-phase feeding program was applied: 1 to 8 d-old a pre-starter diet (300g/bird), 9 to 21 a starter diet $(900 \mathrm{~g} /$ bird), 22 to 35 a grower diet (2200g/bird), and 36 to 42 a finisher diet (1000g/bird). Feeds were based on soybean meal and tannin-free sorghum or corn, and were formulated according to the nutritional and energy levels recommended by Rostagno et al. (2005).
The concentration of tannin in grain sorghum used in this study was $42,7 \mathrm{mg} / \mathrm{kg}$ of sorghum, equivalent to $0.00427 \%$ (CBAA method for HPLC with UV detector). This value is so low that classification is tannin-free sorghum. During the experiment the feed average particle size of whole-grain sorghum was $1,815 \mathrm{~mm}$, ground corn $0,79 \mathrm{~mm}$ and ground sorghum $0,82 \mathrm{~mm}$. Feeds were chemically analyzed at the Animal Nutrition Laboratory of the School of Veterinary Medicine (LAMRA) of UFU and the results are shown in Tables 1 and 2. Diets supplied in each phase were formulated to contain equal energy and nutrient levels.

Table 1 - Ingredients and calculated nutritional composition of the diets based on sorghum fed broilers during the pre-starter (1 to 7 days), starter (8 to 21 days), grower (21 to 35 days), and finisher (35 to 42 days) phases.

\begin{tabular}{|c|c|c|c|c|}
\hline \multirow[b]{2}{*}{ Ingredients } & \multicolumn{4}{|c|}{ Quantity (kg) } \\
\hline & pre-starter & Starter & Grower & Finisher \\
\hline Sorghum - $8.6 \%$ CP & 54.330 & 56.630 & 58.914 & 61.657 \\
\hline Soybean meal - $46.5 \%$ CP & 37.217 & 34.394 & 31.298 & 28.557 \\
\hline Soybean oil & 4.119 & 5.112 & 6.232 & 6.400 \\
\hline Dicalcium phosphate & 1.947 & 1.582 & 1.342 & 1.312 \\
\hline Limestone & 0.772 & 0.823 & 0.785 & 0.810 \\
\hline Salt & 0.461 & 0.440 & 0.420 & 0.443 \\
\hline L-Lysine HCL & 0.323 & 0.275 & 0.263 & 0.253 \\
\hline DL-Methionine & 0.210 & 0.158 & 0.172 & 0.206 \\
\hline L-Threonine & 0.121 & 0.088 & 0.074 & 0.061 \\
\hline Vitamin and mineral supplement & $0.500^{1}$ & $0.500^{1}$ & $0.500^{2}$ & $0.300^{3}$ \\
\hline TOTAL & 100 & 100 & 100 & 100 \\
\hline \multicolumn{5}{|l|}{ Calculated nutritional composition } \\
\hline Crude protein & 22.500 & 21.283 & 20.027 & 19.066 \\
\hline Calcium & 0.920 & 0.841 & 0.758 & 0.663 \\
\hline Available phosphorus & 0.470 & 0.401 & 0.354 & 0.309 \\
\hline Potassium & 0.858 & 0.814 & 0.764 & 0.726 \\
\hline Sodium & 0.220 & 0.210 & 0.200 & 0.195 \\
\hline Chlorine & 0.284 & 0.271 & 0.259 & 0.253 \\
\hline Linoleic acid & 3.117 & 3.659 & 4.268 & 4.378 \\
\hline Digestible lysine & 1.324 & 1.217 & 1.131 & 1.060 \\
\hline Digestible methionine & 0.672 & 0.607 & 0.571 & 0.529 \\
\hline Digestible methionine + cystine & 0.953 & 0.876 & 0.906 & 0.774 \\
\hline Digestible threonine & 0.861 & 0.791 & 0.735 & 0.689 \\
\hline Digestible tryptophan & 0.256 & 0.242 & 0.226 & 0.213 \\
\hline Digestible arginine & 1.400 & 1.315 & 1.221 & 1.145 \\
\hline Apparent metabolizable energy & 2.9600 & 3.0500 & 3.1500 & 3.2000 \\
\hline
\end{tabular}

${ }^{1}$ Broiler starter premix: Folic acid 140,000 mg/kg, pantothenic acid $1600 \mathrm{mg} / \mathrm{kg}$, Zn bacitracin $11,000 \mathrm{~g} / \mathrm{kg}$, biotin 12,000 mg/kg, Cu 1260,000 mg/kg, choline $70 \mathrm{~g} / \mathrm{kg}$, Fe $10.5 \mathrm{~g} / \mathrm{kg}$, I $252 \mathrm{mg} / \mathrm{kg}$, Mn12.6 g/kg, Met $336.600 \mathrm{~g} / \mathrm{kg}$, sodium monensin (exact) $22 \mathrm{~g} / \mathrm{kg}$, niacin $6000 \mathrm{mg} / \mathrm{kg}$, selenium $80 \mathrm{mg} / \mathrm{kg}$, VitA $1.600,000$ IU/kg, VitB1 600,000 mg/kg, VitB12 2,000 mcg/kg, VitB2 800 mg/kg, VitB6 400,000 mg/kg, VitD3 400,000 $\mathrm{IU} / \mathrm{kg}$, VitE $3,000 \mathrm{mg} / \mathrm{kg}$, VitK $400 \mathrm{mg} / \mathrm{kg}$, Zn $12.600 \mathrm{~g} / \mathrm{kg}$.

${ }^{2}$ Broiler grower premix: Folic acid 100,000 mg/kg, pantothenic acid $1600 \mathrm{mg} / \mathrm{kg}$, biotin $6,000 \mathrm{mg} / \mathrm{kg}$, Cu $1200,0000 \mathrm{mg} / \mathrm{kg}$, choline $50 \mathrm{~g} / \mathrm{kg}$, Fe $10.0 \mathrm{~g} / \mathrm{kg}$, Halquinol exact $6000 \mathrm{mg} / \mathrm{kg}$, 240 mg/kg, Mn12.0 g/kg, Met $267.300 \mathrm{~g} / \mathrm{kg}$, niacin $4800 \mathrm{mg} / \mathrm{kg}$, salinomycin exact $13.200 \mathrm{~g} / \mathrm{kg}$, selenium $60 \mathrm{mg} / \mathrm{kg}$, VitA 1.280,000 IU/kg, VitB1 400,000 mg/kg, VitB12 1.600 mcg/kg, VitB2 720 mg/kg, VitB6 320,000 mg/kg, VitD3 350,000 $\mathrm{IU} / \mathrm{kg}$, VitE 2,400 mg/kg, VitK $300 \mathrm{mg} / \mathrm{kg}$, Zn 12,000 g/kg.

${ }^{3}$ Broiler finisher premix: Folic acid 100,000 mg/kg, pantothenic acid $1333 \mathrm{mg} / \mathrm{kg}$, biotin 6,670 mg/kg, Cu 2000,000 mg/kg, choline $50 \mathrm{~g} / \mathrm{kg}$, Fe $16.60 \mathrm{~g} / \mathrm{kg}$, $400 \mathrm{mg} / \mathrm{kg}$, Mn $20.0 \mathrm{~g} / \mathrm{kg}$, Met 230,000 g/kg, niacin $4000 \mathrm{mg} / \mathrm{kg}$, virginiamycin exact 3,666 mg/kg, selenium 60,680 mg/kg, VitA 1,300,260 IU/kg, VitB1 166,000 mg/kg, VitB12 $1.667 \mathrm{mcg} / \mathrm{kg}$, VitB2 $666.800 \mathrm{mg} / \mathrm{kg}$, VitB6 200,000 mg/kg, VitD3 400,000 IU/kg, VitE $2,167.10 \mathrm{mg} / \mathrm{kg}$, VitK $333.400 \mathrm{mg} / \mathrm{kg}$, Zn $20,000 \mathrm{~g} / \mathrm{kg}$ 
Table 2 - Ingredients and calculated nutritional composition of the diets based on corn fed to broilers during the pre-starter (1 to 7 days), starter (8 to 21 days), grower (21 to 35 days), and finisher (35 to 42 days) phases.

\begin{tabular}{|c|c|c|c|c|}
\hline \multirow[b]{2}{*}{ Ingredients } & \multicolumn{4}{|c|}{ Quantity (kg) } \\
\hline & pre-starter & Starter & Grower & Finisher \\
\hline Corn grain $-8 \% \mathrm{CP}$ & 56.423 & 58.740 & 61.598 & 64.959 \\
\hline Soybean meal - $46.5 \%$ CP & 37.334 & 34.579 & 31.062 & 28.195 \\
\hline Soybean oil & 2.002 & 2.918 & 3.864 & 3.869 \\
\hline Dicalcium phosphate & 1.841 & 1.471 & 1.228 & 0.986 \\
\hline Limestone & 0.830 & 0.883 & 0.850 & 0.779 \\
\hline Salt & 0.447 & 0.425 & 0.404 & 0.394 \\
\hline L-Lysine $\mathrm{HCL}$ & 0.308 & 0.258 & 0.259 & 0.256 \\
\hline DL-Methionine & 0.191 & 0.137 & 0.153 & 0.189 \\
\hline L-Threonine & 0.124 & 0.089 & 0.082 & 0.073 \\
\hline Vitamin and mineral supplement & $0.500^{1}$ & $0.500^{1}$ & $0.500^{2}$ & $0.300^{3}$ \\
\hline Total & 100 & 100 & 100 & 100 \\
\hline \multicolumn{5}{|l|}{ Calculated nutritional composition } \\
\hline Crude protein & 22.400 & 21.200 & 19.800 & 18.749 \\
\hline Calcium & 0.920 & 0.841 & 0.760 & 0.663 \\
\hline Available phosphorus & 0.470 & 0.401 & 0.354 & 0.309 \\
\hline Potassium & 0.856 & 0.812 & 0.756 & 0.714 \\
\hline Sodium & 0.220 & 0.210 & 0.200 & 0.195 \\
\hline Chlorine & 0.318 & 0.301 & 0.290 & 0.287 \\
\hline Linoleic acid & 1.776 & 2.268 & 2.776 & 2.784 \\
\hline Digestible lysine & 1.324 & 1.217 & 1.131 & 1.060 \\
\hline Digestible methionine & 0.660 & 0.595 & 0.559 & 0.517 \\
\hline Digestible methionine + cystine & 0.953 & 0.876 & 0.826 & 0.774 \\
\hline Digestible threonine & 0.861 & 0.791 & 0.735 & 0.689 \\
\hline Digestible tryptophan & 0.243 & 0.228 & 0.209 & 0.194 \\
\hline Digestible arginine & 1.416 & 1.333 & 1.228 & 1.145 \\
\hline Apparent metabolizable energy & 2.9600 & 3.0500 & 3.1500 & 3.200 \\
\hline
\end{tabular}

${ }_{1}^{1}$ Broiler premix - starter: Folic acid 140,000 mg/kg, pantothenic acid $1600 \mathrm{mg} / \mathrm{kg}$, Zn bacitracin 11,000 g/ kg, biotin 12,000 mg/kg, Cu 1260,0000 mg/kg, choline 70 g/ $/ \mathrm{kg}$, Fe $10.5 \mathrm{~g} / \mathrm{kg}, \mathrm{I} 252 \mathrm{mg} / \mathrm{kg}, \mathrm{Mn} 12.6 \mathrm{~g} /$ $\mathrm{kg}$, Met $336.600 \mathrm{~g} / \mathrm{kg}$, sodium monensin (exact) $22 \mathrm{~g} / \mathrm{kg}$, niacin $6000 \mathrm{mg} / \mathrm{kg}$, selenium $80 \mathrm{mg} / \mathrm{kg}$, VitA $1.600,000 \mathrm{IU} / \mathrm{kg}$, VitB1 600,000 mg/kg, VitB12 2,000 mcg/kg, VitB2 $800 \mathrm{mg} / \mathrm{kg}$, VitB6 400,000 mg/kg, VitD3 400,000 IU/kg, VitE 3,000 mg/kg, VitK $400 \mathrm{mg} / \mathrm{kg}$, Zn $12.600 \mathrm{~g} / \mathrm{kg}$.

${ }^{2}$ Broiler grower premix: Folic acid 100,000 mg/kg, pantothenic acid $1600 \mathrm{mg} / \mathrm{kg}$, biotin 6,000 mg/kg, Cu 1200,0000 mg/kg, choline $50 \mathrm{~g} / \mathrm{kg}$, Fe $10.0 \mathrm{~g} / \mathrm{kg}$, Halquinol exact $6000 \mathrm{mg} / \mathrm{kg}, 1240 \mathrm{mg} / \mathrm{kg}, \mathrm{Mn} 12.0 \mathrm{~g} / \mathrm{kg}$, Met $267.300 \mathrm{~g} / \mathrm{kg}$, niacin $4800 \mathrm{mg} / \mathrm{kg}$, salinomycin exact $13.200 \mathrm{~g} / \mathrm{kg}$, selenium $60 \mathrm{mg} / \mathrm{kg}$, VitA 1.280,000 IU/kg, VitB1 400,000 mg/kg, VitB12 1.600 mcg/kg, VitB2 720 mg/kg, VitB6 320,000 mg/kg, VitD3 350,000 IU/kg, VitE 2,400 mg/kg, VitK $300 \mathrm{mg} / \mathrm{kg}, Z n 12,000 \mathrm{~g} / \mathrm{kg}$.

${ }^{3}$ Broiler finisher premix: Folic acid 100,000 mg/kg, pantothenic acid $1333 \mathrm{mg} / \mathrm{kg}$, biotin 6,670 mg/kg, Cu 2000,000 mg/kg, choline $50 \mathrm{~g} / \mathrm{kg}$, Fe $16.60 \mathrm{~g} / \mathrm{kg}, 1400 \mathrm{mg} / \mathrm{kg}$, Mn $20.0 \mathrm{~g} / \mathrm{kg}$, Met 230,000 g/kg, niacin $4000 \mathrm{mg} / \mathrm{kg}$, virginiamycin exact 3,666 mg/kg, selenium60,680 mg/kg, VitA 1,300,260 IU/kg, VitB1 166,000 mg/kg, VitB12 $1.667 \mathrm{mcg} / \mathrm{kg}$, VitB2 $666.800 \mathrm{mg} / \mathrm{kg}$, VitB6 200,000 mg/kg, VitD3 400,000 IU/kg, VitE $2,167.10 \mathrm{mg} / \mathrm{kg}$, VitK $333.400 \mathrm{mg} / \mathrm{kg}$, Zn 20,000 g/kg.

The treatments consisted of ground corn, wholegrain sorghum and ground sorghum since prestarter diet. The lighting program adopted during the experiment changed with bird age: 1 to $7 \mathrm{~d}$-old 22 hours of light, 8 to $21 \mathrm{~d}$-old 20 hours and 22 to 42 d-old 23 hours.

To evaluate the gastrointestinal tract, on day 41 birds were weighed, and the males which body weight similar $( \pm 5 \%)$ to the average body weight in the same treatment were selected. On day 42, the 15 males selected on the previous day (five per treatment) were fasted for 12 hours, and weighed again at the time of sacrifice in a digital scale (Balmak brand, Brazil line M) with 5-g precision. Birds were then sacrificed by neck dislocation.

After sacrifice, organs and the entire gastrointestinal tube were collected. proventriculus, gizzard, pancreas, liver, heart, and intestines were immediately and individually weighed in a semi-analytical scale (Marte brand, number BL3200H) with 0.01 -g precision. Intact small intestine length, i.e., from the beginning of the duodenum to the ileal-cecal junction, was measured using a $0.1-\mathrm{cm}$ scale measuring tape. Tissue samples for morphological measurements were taken from the duodenum (5 $\mathrm{cm}$ from the pylorus), jejunum ( $5 \mathrm{~cm}$ posterior to the yolk stalk), and ileum ( $2 \mathrm{~cm}$ anterior to the ileo-cecal valve), as described by Zang et al. (2009). The cecum and colon was also collected based on ileo-cecal valve and cloaca.

Fragments measuring approximately $3 \mathrm{~cm}$ long were collected from the middle portion of the duodenum, jejunum, and ileum per bird. Each fragment was placed in a duly identified flask $(50 \mathrm{~mL})$ with a screw cap, containing 10\% formaldehyde water solution for fixation. After 72 hours, the flasks were submitted to the Histology Laboratory of UFU, where the material was processed.

Three $0.5 \mathrm{~cm}$ semi-serial rings were collected from each fragment and placed in a single histological cassette, duly identified and placed in a solution of $70 \%$ ethylic alcohol in distilled water. Samples were processed in an automated histology equipment (LUPE TEC, model PT 05), dehydrated in graded series of alcohol, cleared in xylol, and embedded in paraffin.

Serial 5.0- $\mu \mathrm{m}$ thick sections were obtained using a manual microtome, and placed on slides. Tissue sections were then stained, using the routine Harris hematoxylin and eosin procedure (H.E.), and mounted using Entellan ${ }^{\circledR}$ resin and $24 \times 60$ cover slips (Junqueira \& Carneiro, 1982).

The following parameters were evaluated at 42-d-old: live weight; feed conversion ratio; gizzard absolute weight; proventriculus; liver, pancreas, and 
heart relative weight; intact small intestine, cecum and colon relative lengths; and villus height and width, distance between villus bases, crypt depth, and absorption surface area of the duodenum, jejunum and ileum

The measured parameters were expressed as: grams for live weight and gizzard weight; grams per 100 grams of live weight $(\mathrm{g} / 100 \mathrm{~g})$ for organ relative weight, except gizzard; and centimeters per 100 grams of live weight $(\mathrm{cm} / 100 \mathrm{~g})$ for relative length of the intestinal segments. Organs relative weights were calculated based on organ weight multiplied by 100 and divided by the live weight. Intestines relative lengths were calculated based on intestine length multiplied by 100 and divided by the live weight.

Thirty measures were randomly taken per treatment: villus height and width; distance between villi; crypt depth. The villus height was measured from the tip of the villus to the villus-crypt junction. The villus width was defined as the distance from the outside epithelial edge to the outside of the opposite epithelial edge along a line passing through the vertical midpoint of the villus. The crypt depth was defined as the depth of the invagination between adjacent villi (Wang \& Peng, 2008). The distance between villi was measured at the base, taken from the central distance between two villi. Absorption surface area was determined as the times the intestinal mucosa increases, according to the calculations proposed by Kisielinski et al. (2002).

Duodenum, jejunum, and ileum section images were captured at $2 \mathrm{x}$ magnitude in a light microscope (Olympus Triocular BH2) coupled to a camera (JVC TK1085U) linked to a computer by a frame grabber (Data Translation 3153). Villus length was measured using the software program HL Image 97 (Western Vision Softwares).

The obtained data were submitted to Shapiro-Wilk normality test and to analysis of variance. Means were compared by the test of Tukey at 5\% significance level, using the GLM procedure of SAS statistical package, version 9.2 (Statistical Analysis System, 2008).

\section{RESULTS AND DISCUSSION}

Live weight and feed conversion ratio, of 42-d-old broilers fed diets based on whole-grain sorghum or ground sorghum, had better results compared to ground corn (Table 3), proving that regardless of the physical form, sorghum showed better performance results than corn. This results was more interesting than Fernandes et al. (2013) that found no difference in the performance characteristics of 42-d-old broilers, by replacing corn by ground or whole sorghum in similar design, as well as Fernandes et al. (2008) compared ground corn, broken corn, ground sorghum and wholegrain sorghum (50:50) or Murta et al. (2004) with diets based on corn and sorghum with different particle sizes $(1.20 \mathrm{~mm}, 4.763 \mathrm{~mm}, 6.350 \mathrm{~mm}$, or $9.525 \mathrm{~mm})$ or Gualtieri \& Rapaccini (1990), where corn was replaced by sorghum $(0,50$, and $100 \%)$ them did not verify any performance differences in male or female broilers.

Table 3 - Live weight and feed conversion ratio (FCR) of 42-d-old broilers fed diets based on ground corn, wholegrain sorghum or ground sorghum.

\begin{tabular}{lcc}
\hline Treatments & Live weight $(\mathrm{g})$ & $\mathrm{FCR}$ \\
\hline Ground corn & $2206 \mathrm{~b}$ & $1,695 \mathrm{a}$ \\
\hline Whole-grain sorghum & $2309 \mathrm{a}$ & $1,652 \mathrm{~b}$ \\
\hline Ground sorghum & $2323 \mathrm{a}$ & $1,646 \mathrm{~b}$ \\
\hline $\mathrm{CV}(\%)$ & 2.55 & 1.87 \\
\hline P value & 0.0011 & 0.0093
\end{tabular}

Means followed by different letters in the same column are different by the test of Tukey at $5 \%$ significance level $(p<0.05)$

Gizzard absolute weight was higher $(p<0.05)$ when broilers were fed whole-grain sorghum and lower when fed ground corn, whereas ground sorghum was not different from the other treatments (Table 4). These results are consistent with the hypothesis that coarse feedstuffs promote muscle hypertrophy in the gizzard because of the effort to reduce particle size. Results of Ribeiro et al. (2002) corroborate this work to assess the size of food particles in chickens, and it was observed that the gizzard weight also increased when the diet contained large particles, suggesting that gizzard size is related to the development of the longitudinal smooth muscles due to the mechanical work needed to grind the feed. It must be noted that the greater the particle size, the longer the feedstuff needs to remain in the gizzard in order to be reduced (Turk, 1982). This would allow better exposure of the digesta to hydrochloric acid and digestive enzymes, thereby improving feed digestibility, which may explain the higher live weight of the birds fed grain sorghum in the present experiment.

Liver relative weight was higher $(p<0.05)$ when 42 - $d$-olf broilers were fed ground corn and lower $(p<0.05)$ when ground sorghum was offered, while the whole-grain sorghum treatment was not different from the others (Table 4), suggesting a tendency to equal response of the tested diets. This result was confirmed by Garcia et al. (2005), in broilers evaluated at $14,21,28,35$, and 42 days of age, did not find any 
Table 4 - Absolute gizzard weight, proventriculus, liver, pancreas, and heart relative weights of 42-d-old broilers fed diets based on ground corn, whole-grain sorghum or ground sorghum.

\begin{tabular}{lccccc}
\hline Treatments & $\begin{array}{c}\text { Gizzard } \\
(\mathrm{g})\end{array}$ & Proventriculus $(\mathrm{g} / 100 \mathrm{~g})$ & $\begin{array}{c}\text { Liver } \\
(\mathrm{g} / 100 \mathrm{~g})\end{array}$ & $\begin{array}{c}\text { Pancreas } \\
(\mathrm{g} / 100 \mathrm{~g})\end{array}$ & Heart $(\mathrm{g} / 100 \mathrm{~g})$ \\
\hline Ground corn & $36.770 \mathrm{~b}$ & 0.357 & $3.020 \mathrm{a}$ & 0.231 & 0.5205 \\
\hline Whole-grain sorghum & $47.064 \mathrm{a}$ & 0.325 & $2.650 \mathrm{ab}$ & 0.213 & 0.6114 \\
\hline Ground sorghum & $39.504 \mathrm{ab}$ & 0.328 & $2.348 \mathrm{~b}$ & 0.193 & 0.5446 \\
\hline $\mathrm{CV}(\%)$ & 12.52 & 8.34 & 16.38 & 13.45 & 16.18 \\
\hline$p$ value & 0.0217 & 0.0659 & 0.0202 & 0.0589 & 0.2067 \\
\hline
\end{tabular}

Means followed by different letters in the same column are different by the test of Tukey at $5 \%$ significance level $(p<0.05)$

differences in proventriculus, pancreas, or liver relative weights when corn and high- or low-tannin sorghum were fed.

There was no difference ( $p>0.05$ ) among treatments relative to duodenum, ileum, cecum, or colon relative weights, of 42-d-old broilers (Table 5). However, jejunum relative weight was higher $(p>0.05)$ when broilers were fed ground corn compared with ground sorghum, which was not different from the wholegrain sorghum treatment, possibly a tendency to equal response of the tested diets. Although the jejunum is where most of the digestion and intestinal absorption occur (Vieira, 2002), in spite of the higher value of jejunum relative weight in broilers fed ground corn compared to ground sorghum, there was not a greater live weight and feed conversion ratio.

Table 5 - Duodenum, jejunum, ileum, cecum, and colon relative weights of 42 -d-old male broilers fed diets based on ground corn, whole-grain sorghum or ground sorghum.

\begin{tabular}{lccccc}
\hline Treatments & $\begin{array}{c}\text { Duodenum } \\
(\mathrm{g} / 100 \mathrm{~g})\end{array}$ & $\begin{array}{c}\text { Jejunum } \\
(\mathrm{g} / 100 \mathrm{~g})\end{array}$ & $\begin{array}{c}\text { Ileum } \\
(\mathrm{g} / 100 \mathrm{~g})\end{array}$ & $\begin{array}{c}\text { Cecum } \\
(\mathrm{g} / 100 \mathrm{~g})\end{array}$ & $\begin{array}{c}\text { Colon } \\
(\mathrm{g} / 100 \mathrm{~g})\end{array}$ \\
\hline Ground corn & 0.739 & $1.599 \mathrm{a}$ & 1.280 & 0.490 & 0.159 \\
\hline $\begin{array}{l}\text { Whole-grain } \\
\text { sorghum }\end{array}$ & 0.696 & $1.461 \mathrm{ab}$ & 1.186 & 0.493 & 0.177 \\
\hline $\begin{array}{l}\text { Ground } \\
\text { sorghum }\end{array}$ & 0.715 & $1.235 \mathrm{~b}$ & 0.990 & 0.490 & 0.132 \\
\hline $\mathrm{CV}(\%)$ & 16.67 & 18.24 & 24.88 & 5.47 & 25.99 \\
\hline p value & 0.8129 & 0.0441 & 0.2131 & 0.9729 & 0.1625 \\
\hline
\end{tabular}

Means followed by different letters in the same column are different by the test of Tukey at $5 \%$ significance level $(p<0.05)$

The results obtained for the three segments of the small intestine are different from those of Fernandes et al. (2008), who found an increase in small intestine relative weight in 42-d-old broilers fed 50 or $100 \%$ sorghum in replacement of corn. Those authors did not observe any influence of feed physical form on cecum weight. Although Dahlke et al. (2003) and Nir et al. (1995) demonstrated that dietary particle size affects intestinal weight and size, Garcia et al. (2005), did not observe any effect of the substitution of corn by sorghum on intestinal relative weight, which is consistent with the findings of the present study.

There was no effect of treatment ( $p>0.05$ ) on entire small intestine, cecum, or colon relative lengths (Table 6). These results are consistent with those reported by Fernandes et al. (2008), who compared diets based on ground corn, ground sorghum, ground and wholegrain sorghum (50:50), or whole-grain sorghum for broilers, and did not find any differences in small intestine length. Garcia et al. (2005) also found no influence of diets based on corn or low- and hightannin sorghum on small intestine or cecum length of broilers.

Table 6 - Whole small intestine, cecum and colon relative lengths of 42-d-old male broilers fed diets based on ground corn, whole-grain sorghum or ground sorghum.

\begin{tabular}{lccc}
\hline Treatments & $\begin{array}{c}\text { Small intestine } \\
(\mathrm{cm} / 100 \mathrm{~g})\end{array}$ & $\begin{array}{c}\text { Cecum } \\
(\mathrm{cm} / 100 \mathrm{~g})\end{array}$ & $\begin{array}{c}\text { Colon } \\
(\mathrm{cm} / 100 \mathrm{~g})\end{array}$ \\
\hline Ground corn & 6.208 & 1.387 & 0.286 \\
\hline $\begin{array}{l}\text { Whole-grain } \\
\text { sorghum }\end{array}$ & 5.863 & 1.286 & 0.255 \\
\hline Ground sorghum & 5.596 & 1.239 & 0.256 \\
\hline $\mathrm{CV}(\%)$ & 11.99 & 11.69 & 18.03 \\
\hline $\mathrm{p}$ value & 0.3380 & 0.2385 & 0.5353 \\
\hline
\end{tabular}

Test of Tukey at $5 \%$ significance level $(p<0.05)$

There was no effect of treatment ( $p>0.05$ ) on villus height and width, villus distance and absorption surface area in the small intestines, of 42-d-old broilers (Table 7). However, broilers fed ground sorghum presented shallower duodenum crypts compared with those fed whole-grain sorghum. The treatment with ground corn was not different from the others. This result may suggest that the duodenum mucosa of birds fed whole-grain sorghum suffered more damage than in the other treatments, because crypt depth increases according to epithelium turnover needs (Macari, 1995; Boleli et al., 2002). Despite the energy losses with cell turnover, this response may be beneficial to the 
intestine, as shown by the higher live weight of the broilers at 42 days of age. Deeper crypts, suggesting higher cell proliferation in the intestinal epithelium, is a response of the body in an attempt to maintain villus characteristics, that is, to maintain absorption surface area (Uni et al., 1998; Uni et al., 2000).

Broilers fed ground corn presented the shallowest crypts in jejunum $(p<0.05)$ compared to those fed whole-grain sorghum. This may be explained by the fact that whole-grain sorghum may have been more aggressive to the epithelium, leading to higher cell proliferation in the crypts, which, therefore, were deeper (Macari, 1995; Boleli et al., 2002). However, absorption surface area in the jejunum was not different among treatments ( $p>0.05)$, indicating that the tested feedstuffs, in particular free-tannin sorghum, did not interfere in the absorption mechanisms at this intestinal segment as observed in the duodenum.

There was no effect of treatment $(p>0.05)$ on morphometric characteristics of the ileum. These results suggest that, independently of treatment, the digesta arriving at the ileum had already been submitted to maximum enzyme activity and maximum absorption in the previous intestinal segments. Due its stable $\mathrm{pH}$ and lower availability of nutrients for absorption, digesta is less aggressive towards the intestinal mucosa, and therefore, it does not influence the structure of the epithelium, and consequently, absorption surface area.

When evaluating the effect of corn replacement by low-tannin sorghum in the diet of one- to 42-d-old broilers, similar to this study, Campos (2006) did not observe any influence on villus height in any of the intestinal segments; however, villus height continuously increased with bird age.

Consistent with the results of the present study, Uni et al. (1998), Oliveira et al. (2000), and Geyra et al. (2001) reported that the duodenum and the jejunum present high cell proliferation and migration rates, as well as high villi and deep crypts, because they are submitted to stronger aggression and stimuli. Ribeiro et al. (2002) did not find any effects of increasing corn particle size on duodenal morphology (villus number and height) in 21- to 42-d-old male broilers, but that villus number and height increased with age.

\section{CONCLUSIONS}

Whole or ground grain sorghum may replace corn in the feed of 1- to 42-d-old broilers, since they improve body weight and feed conversion ratio, and not adversely affect intestinal morphometry and organs weight.

Table 7 - Villus height and width, distance between villus bases, crypt depth, and absorption surface area of the duodenum, jejunum and ileum of 42-d-old male broilers fed diets based on ground corn, whole-grain sorghum or ground sorghum.

\begin{tabular}{|c|c|c|c|c|c|}
\hline Treatments & $\begin{array}{l}\text { Height } \\
(\mu \mathrm{m})\end{array}$ & $\begin{array}{l}\text { Width } \\
(\mu \mathrm{m})\end{array}$ & $\begin{array}{l}\text { Distance } \\
\quad(\mu \mathrm{m})\end{array}$ & $\begin{array}{l}\text { Crypt } \\
(\mu \mathrm{m})\end{array}$ & $\begin{array}{c}\text { Absorption surface } \\
\text { area }\end{array}$ \\
\hline \multicolumn{6}{|c|}{ Duodenum } \\
\hline Ground corn & 1736.648 & 204.110 & 134.594 & $274.823 a b$ & 12.986 \\
\hline Whole-grain sorghum & 1596.992 & 218.259 & 117.297 & $332.305 \mathrm{a}$ & 12.896 \\
\hline Ground sorghum & 1821.906 & 217.068 & 133.633 & 263.152 b & 13.727 \\
\hline CV $(\%)$ & 14.73 & 11.01 & 25.59 & 12.97 & 24.05 \\
\hline$p$ value & 0.3947 & 0.6331 & 0.6559 & 0.0288 & 0.9027 \\
\hline \multicolumn{6}{|c|}{ Jejunum } \\
\hline Ground corn & 1318.410 & 148.818 & 82.231 & $239.261 \mathrm{~b}$ & 15.263 \\
\hline Whole-grain sorghum & 1618.780 & 166.941 & 94.705 & 315.722 a & 16.482 \\
\hline Ground sorghum & 1505.330 & 169.524 & 86.758 & $263.323 \mathrm{ab}$ & 16.173 \\
\hline CV $(\%)$ & 18.08 & 20.35 & 22.26 & 15.21 & 9.37 \\
\hline$p$ value & 0.1500 & 0.5709 & 0.6070 & 0.0361 * & 0.4338 \\
\hline \multicolumn{6}{|c|}{ Ileum } \\
\hline Ground corn & 993.308 & 181.132 & 83.054 & 199.394 & 10.946 \\
\hline Whole-grain sorghum & 1157.130 & 182.774 & 77.277 & 233.119 & 12.460 \\
\hline Ground sorghum & 1131.632 & 180.078 & 83.427 & 231.519 & 11.328 \\
\hline CV $(\%)$ & 18.25 & 9.66 & 8.03 & 11.57 & 19.29 \\
\hline$p$ value & 0.4052 & 0.9704 & 0.3406 & 0.1033 & 0.5539 \\
\hline
\end{tabular}

Test of Tukey at $5 \%$ significance level $(p<0.05)$ 


\section{REFERENCES}

Boleli IC, Maiorka A, Macari M. Estrutura funcional do trato digestório. In: Macari, M.; Furlan, R.L.; Gonzales, E, editor. Fisiologia Aviária Aplicada a frangos de corte. Jaboticabal: Funep-Unesp; 2002. p. 75-95.

Campos DMB. Efeito do sorgo sobre o desempenho zootécnico, características da carcaça e o desenvolvimento da mucosa intestinal de frangos. [Dissertação]. Jaboticabal (SP): Universidade Estadual Paulista; 2006.

Carolino ACXG, SILVA MCA, Litz, FH, Fagundes NS, Fernandes EA. Rendimento e composição de carcaça de frangos de corte alimentados com dietas contend sorgo grão inteiro. Bioscience Journal 2014; 30(4): 1139-1148.

Dahlke F, Ribeiro AML, Kessler AM, Lima AR, Maiorka A. Effects of corn particle size and physical form of the diet on the gastrointestinal structures of broiler chickens. Revista Brasileira de Ciência Avícola 2003; 5(1): 61-67.

Fernandes EA, Pereira WJS, Hackenhaar L, Rodrigues RM, Terra R. The use of whole grain sorghum in broiler feeds. Brazilian Journal of Poultry Science 2013; 15(3):217-222.

Fernandes EA, Rodrigues RM, Hackenhaar L, Klink UP, Fagundes NS, Caires CM. Uso de grão de sorgo integral na alimentação de frangos de corte. Revista Brasileira de Ciência Avícola 2008; sup.10: p. 87

Gabriel I, Mallet S, Leconte M, Travel A, Lalles JP. Effects of whole wheat feeding on the development of the digestive tract of broiler chickens. Animal Feed Science and Technology 2008; 142: 144-162.

Garcia RG, Mendes AA, Almeida Paz ICL, Komiyama CM, Caldara FR, Nääs IA, Mariano WS. Implications of the use of sorghum in broiler production. Brazilian Journal of Poultry Science 2013; 15(3): 257-262.

Garcia RG, Mendes AA, Andrade C, Paz ICLA, Takahashi SE, Pelicia K, Komiyama CM, Quinteiro RR. Avaliação do desempenho e de parâmetros gastrintestinais de frangos de corte alimentados com dietas formuladas com sorgo alto tanino e baixo tanino. Ciência e Agrotecnologia 2005; 29(6): 1248-1257.

Geyra A, Uni Z, Sklan D. The effect of fasting at different ages on growth and tissue dynamics in the small intestine of the young chick. British Journal of Nutrition, Cambridge 2001; 86:53-61.

Gualtieri M, Rapaccini S. Sorghum grain in poultry feeding. World's Poultry Science Journal 1990; 46:246-254.

Junqueira LC, Carneiro J. Histologia básica. 1st ed. Rio de Janeiro, RJ: Guanabara Koogan; 1985.

Kisielinski K, Willi S, Prescher A, Klosterhalfen B, Schumpelick V. A simple new method to calculate small intestine absorptive surface in the rat. Clinical and Experimental Medicine 2002; 2(3):131-135.

Macari M. Mecanismos de proliferação e reparação da mucosa gastrintestinal em aves. In I Simpósio de Coccidiose e Enterite; 1995; Campinas, São Paulo. Brasil. p.1995.

Maiorka A, Boleli IC, Macari M. Desenvolvimento e reparo da mucosa intestinal. In: Macari M, Furlan RL, Gonzales E, editor. Fisiologia aviária aplicada a frangos de corte. Jaboticabal: Funep-Unesp; 2002. p. 113123

Morais E, Franco SG, Fedalto LM. Efeitos da substituição do milho pelo sorgo, com adição de enzimas digestivas, sobre o ganho médio de peso de frangos de corte. Archives of Veterinary Science 2002; 7(2):109-14.

Murta GPO, Fernandes EA, Olegário MMM, Silva CB, Pereira PC. Efeito da moagem do sorgo grão sobre o desempenho de frangos de corte. Revista Brasileira de Ciência Avícola 2004; 6:32.

Nir I, Hillel R, Ptichi I, Shefet G. Effect of particle size on performance. 3. Grinding pelleting interactions. Poultry Science 1995; 74:771-783.

Oliveira PB, Murakami AE, Garcia ERM, Macari M, Scapinello C. Influência de fatores antinutricionais da leucena (Leucaena leucocephala e Leucaena eunningan) e do Feijão Guandu (Cajanus cajan) sobre o epitélio intestinal e o desempenho de frangos de corte. Revista Brasileira de Zootecnia: 2000; 29(6): 1759-1769.

Pimentel ACS, Júnior WMD, Ludke MCMM, Ludke JV, Rabello CBV, Freitas CRG. Substituição parcial do milho e farelo de soja por sorgo e farelo de caroço de algodão extrusado em rações de frangos de corte. Acta Scientiarum Animal Science 2007; 29(2): 135-141.

Ribeiro AML, Magro N, Penz Junior AM. Granulometria do milho em rações de crescimento de frangos de corte e seu efeito no desempenho e metabolismo. Revista Brasileira de Ciência Avícol 2002; 4(1).

Rocha VRRA, Júnior WMD, Rabello CB, Ramalho RP, Ludke MCMM, Silva EC. Substituição total do milho por sorgo e óleo de abatedouro avícola em dietas para frangos de corte. Revista Brasileira de Zootecnia 2008; 37(1): 95-102.

Rostagno HS, Albino LFT, Donzele JL, Gomes PC, Oliveira RF, Lopes DC, Ferreira AL, Barreto SLT. Tabelas brasileiras para aves e suínos: composição de alimentos e exigências nutricionais. 2 ed.Viçosa (MG): Imprensa Universitária; 2005.

SAS. SAS/STAT® 9.2 User's guide. Version 9.2, Cary, NC: SAS Institute Inc., 2008.

Turk DE. The anatomy of the avian digestive tract as related to feed utilization. Poultry Science Journal 1982; 60(1):101-111.

Uni Z. Vitamin A deficiency interferes with proliferation and maturation of cells in the chickens small intestine. British Poultry Science 2000; 41(4):410-415.

Uni Z, Noy Y, Sklan D. Cell proliferation in chickens intestinal epithelium occurs both in the cript and along the villus. Journal Comparative Physiology B 1998; 168(4):241-247.

Vieira SL. Carboidratos: Digestão e Absorção. In: Macari M, Furlan RL, Gonzales E, editor. Fisiologia aviária aplicada a frangos de corte. Jaboticabal: Funep-Unesp; 2002. p. 130-131.

Wang JX, Peng KM. Developmental Morphology of the Small Intestine of African Ostrich Chicks. Poultry Science 2008; 87:2629-2635.

Zang JJ, Piao XS, Huang DS, Wang JJ, Ma X, Ma YX. Effects of feed particle size and feed form on growth performance, nutrient metabolizability and intestinal morphology in broiler chickens. Asian-Australasian Journal of Animal Science 2009; 22(1):107-112. 
